Bull.Fac, Agric.,Cairo Univ.,62: 29-39 (2011).

\title{
INFLUENCE OF SOME PLANT GROWTH PROMOTING RHIZOBACTERIA (PGPR) ON VEGETATIVE GROWTH, NITROGEN AND PHOSPHORUS CONTENTS AND ANATOMICAL CHARACTERISTICS OF Taxodium distichum Rich. TRANSPLANTS
}

(Received: 26. 9. 2010)

\author{
By \\ H. H. Hammad, A. A. Awad * and O.S. El-Kobisy** \\ Timber Trees and Forestry Department, Horticultural Research Institute, \\ Agricultural Research Center, Giza * Soils, Water and Environment Research Institute, \\ Agricultural Research Center, Giza** Agricultural Botany Department, Faculty of Agriculture, \\ Cairo University, Giza
}

\begin{abstract}
Growth of Taxodium distichum Rich. transplants was stimulated by inoculation with Plant Growth Promoting Rhizobacteria ( PGPR). Results show that significant increases in the plant height, stem diameter, branch number and fresh and dry weights per transplant were observed in the plants inoculated with Azospirillum brasilense. While, higher total phosphorus percentage was found in the plants inoculated with Bacillus polymixa $(0.78 \%)$ compared with the control $(0.45 \%)$ in the stem of Taxodium distichum transplants. Such effects were confirmed by anatomical studies. These results suggest that the growth promoting substances provided by Azospirillum barsilense may enhance the growth of Taxodium distichum transplants and shortening the time of growth.
\end{abstract}

Key words: anatomy, Azospirillum brasilense, Azotobacter chrococcum, Bacillus polymixa, plant growth promoting rhizobacteria (PGPR), and Serratia sp., Taxodium distichum, vegetative growth.

\section{INTRODUCTION}

Taxodium distichum Rich. belongs to family Taxodiaceae which is an unusual and interesting tree often growing over $100 \mathrm{~m}$ in height and over $3 \mathrm{~m}$ in diameter. This beautiful tree is used as a specimen or in small groves particularly in permanent wet areas of the landscape and along roadsides. The wood has a multitude uses and is well known for its ability to resist decay, it is fairly durable and has many uses in outdoor constructions (Bowers and Melhuish, 1988). Cypressene, is an oil extracted from the wood, is believed to give bald cypress high decay resistance. For this reason, cypress wood has long been favored in the building construction fences, posts, planking in boats, doors, shingles, blinds, flooring, caskets, interior trim. cabinetry and many other uses. (Walker 1990). Resins that can be obtained from the cones have been used as an analgesic in folk remedies for skin ailments. Horticultural, bald cypress can be grown on many upland soils and it is seen in cities as a shade tree or ornamental (Wilhite and Toliver,
1990). Gutierrez Manero et al. (1996) reported that the influence of native rhizobacteria on the growth of European alder (Alnus glutinosa Gaertn). PGPR has become a new class of biofertilizers and physiological stimulators in recent years. PGPR have been a renewed interest for inoculation of agricultural crops. PGPR hold great promise as potential agricultural and forestry inoculants and could reduce the use of agrochemicals including chemical fertilizers and pesticides(Zahir et al., 2004). A number of (Rhizobacteria) strains with a positive effect on plant development [Plant Growth Promoting Rhizobatcteria (PGPR)] have been reported ( Belimov et al., 2001).Many strains have been catalogued as (PGPR) due to their effect on plant pathogens (Mei et al., 1984., Schippers et al., 1991; Bashan and de Bashan, 2002 and Al-Kahal et al., 2003) or to their ability to induce plant growth promoting (Bashan,1999 and Mekhamar ,2001). Most of these strains belong to Bacillus, Pseudomonas, Azotobacter, and Azospirillum (Reddy and Rahe 1989). Phytohormones such as 
indol -3- acetic acid (IAA) or cytokinins are among the plant growth promoting compounds often produced by bacteria (Hubble et al., 1979 and Muller et al. 1989). However, other compounds, known as auxins- like IAA ${ }^{-1}$ are often responsible for the promoting effects (Oberhansli et al., 1990 and Selvadurai et al., 1991).

The aim of this work was to investigate the effect of different PGPR strains on growth, N, P content and the anatomical characteristics of Taxodium distichum transplants. Moreover to determine the best treatment that could be used to promote the growth of the seedlings in the nursery.

\section{MATERIALS AND METHODS}

This study was conducted at the nursery of the Timber Trees and Forestry Department, Horticulture Research Institute, Agricultural Research Center, Giza, Egypt with the cooperation with Soils, Water and Environment Res. Institute, Agric. Research Center, Giza , Egypt, and the Agricultural Botany Department, Faculty of Agriculture, Cairo University, Giza during two successive seasons 2008/2009 and 2009/2010.

Seeds of Taxodium distichum Rich .were inoculated with Azospirillum brasilense, Azotobacter chroococcum, Bacillus polymixa and Serratia sp. that were planted in plastic cups $5 \mathrm{~cm}$ diameter filled with sterilized media on the first of January 2008 , at the nursery of the Timber trees and Forestry Department. After three months, the seedlings were transplanted in plastic cups $10 \mathrm{~cm}$ diameter on the first of April 2008. On the $15^{\text {th }}$ of June 2008 homogenous seedlings were transplanted into plastic pots $30 \mathrm{~cm}$ diameter filled by the sterilized container media and inoculated again by the same bacterial strains. The seedlings were placed in a shaded area and after two weeks from transplanting, seedlings were removed outdoors to a sunny area and common cultural practices including regular irrigation were followed ( twice weekly in winter and daily in summer). Every transplant received starter nutrition consisted of NPK $0.5 \mathrm{~g}$ from Kristalon 19:19:19.

\subsection{Organisms and growth conditions}

Azospirillum brasilense (SP 245), Azotobacter chroococcum, Bassillus polymixa and Serratia sp. (Local strain) were supplied by the Microbiology Department, Soils, Water and Environment Research Institute, Agricultural Research Center, Giza, Egypt. Azospirillum was grown in Yeast
Extract Peptone (YEP) medium (Vanstocken et al., 1987) Azotobacter was grown in Asheby medium (Hegazi and Neimela ,1976). Serratia and Bacillus were incubated at $25^{\circ} \mathrm{C}$ for three days until early log phase was developed of $10^{-}$viable ml-, Container media. The container media used in this study were consisted of separated manure, Sphagnum peat and an organic component (vermiculite No-2 ) (1:1:1$\mathrm{v} / \mathrm{v})$. Physical and chemical characteristics of the used media were analyzed before cultivation according to Abdel-Wahab and Ahmed (2003) and their properties are presented in Table (1).

Table(1): Physical and chemical characteristics of the used cultivation media.

\begin{tabular}{|c|c|}
\hline Property & Value \\
\hline $\mathrm{pH}$ & 6.93 \\
\hline E.c. $(\mathrm{ds} / \mathrm{m})$ & 4.23 \\
\hline Organic-C(\%) & 19.65 \\
\hline Total-N(\%) & 1.10 \\
\hline C/N ratio & 17.86 \\
\hline Total $-\mathrm{P}(\%)$ & 0.78 \\
\hline Total $-\mathrm{K}(\%)$ & 1.23 \\
\hline
\end{tabular}

\subsection{Data concerned}

In both seasons 2008/2009 and 2009/2010, the vegetative growth parameters were recorded including plant height $(\mathrm{cm})$, stem diameter, out bark $(\mathrm{mm})$ measured at $10 \mathrm{~cm}$ above soil surface , fresh and dry weights of the shoots and leaves (g/ plant).

\subsection{Chemical composition}

The chemical constituents in dried shoot samples were determined using the method described by Piper (1950) . The nitrogen content were determined using the modified micro Kjeldahl method as described by Pregl (1945), while the phosphorus content was estimated using the method recommended by King (1951).

\subsection{Anatomical characteristics}

The anatomical study was performed on the stem and lateral roots as a cross section at the age of 30 months from transplants planted in first of January 2008 till the first of July 2010. It was intended on plant materials taken from the median portion of the main stem and lateral root. Specimens were killed and fixed for at least $48 \mathrm{hrs}$ in formalin acetic acid (F.A.A) $10 \mathrm{ml}$ formalin , $5 \mathrm{ml}$ glacial acetic acid , $50 \mathrm{ml}$ ethanol alcohol 95\% and containing $35 \mathrm{ml}$ distilled water. The selected 
materials were washed in $50 \%$ ethyl alcohol, dehydrated in a normal butyl alcohol series embedded in paraffin wax of melting point $56^{\circ} \mathrm{C}$, sectioned to a thickness of 20 microns and double stained with crystal violet-erythrosin, cleared in xylene and mounted in Canada balsam, Willey (1971). Sections were analysed to detect histological manifestations of noticeable responses resulted from using Plant Growth Promoting Rhizobacteria.

\subsection{Experimental design and statistical analysis}

The pot experiment was carried in randomized complete blocks design. Each main plot contains 5 treatments each treatment represented 25 replicates. Each replicate consisted of 5 pots, with a single plant per pot. The data were subjected to statistical analysis of variance and the means were compared using the Least Significant Difference (L.S.D) test at 5\% level, as described by Steel and Torrie,( 1980).

\section{RESULTS}

\subsection{Effects of some PGPR on Taxodium distichum} transplants.

\subsubsection{Vegetative growth}

Data presented in Table (2) show that inoculation PGPR to container medium had generally favorable effect on the vegetative growth parameters in both seasons, compared to transplants un- inoculated. Among the different
PGPR strains, Azospirillum brasilense strain was clearly the most effective for promoting vegetative growth of Taxodium distichum transplants in both seasons. In this respect the highest values of plant height, stem diameter, branches number, fresh and dry weights per transplant were $: 91.33 \mathrm{~cm}, 13.4 \mathrm{~mm}$ , 10.00 branches, 73.47 and $21.80 \mathrm{~g}$, respectively, in the first season, and reached $100.00 \mathrm{~cm}, 15 \mathrm{~mm}$, 8,00 branches, 72.50 and $21.50 \mathrm{~g}$,respectively in the second season. In the first season, the percentages of increases as a result of using Azospirillum barsilense, compared to uninoculated medium, were $62.1 \%, 67.5 \%, 233.3 \%, 184.8 \%$ and $161.4 \%$ for plant height, stem diameter, branch number, fresh and dry weights/transplant over the control, respectively.

In addition,data in Table (2) indicate that no significant differences were observed between using the strains of Bacillus ploymixa and Serratia sp. While, Azotobacter chrococcum, gave the least vegetative growth values as compared to any other used strains. The results were confirmed in the second season, with the same applications.

Table (2) indicates that Taxodium disitchum seedlings responded favorably to inoculation with PGPR strains specially Azospirillum brasilense. A similar significant trend was noticed when the growth media was inoculated with PGPR. The growth parameters of the seedlings in the inoculated

Table (2):Influence of PGPR on vegetative growth of Taxodium distichum transplants in both studied seasons 2008 / 2009 and $2009 / 2010$.

\begin{tabular}{|c|c|c|c|c|c|c|c|c|c|c|}
\hline \multirow{2}{*}{ Characters } & \multicolumn{5}{|c|}{ The First season $2008 / 2009$} & \multicolumn{5}{|c|}{ The Second season $2009 / 2010$} \\
\hline & $\begin{array}{c}\text { Plant } \\
\text { height } \\
(\mathrm{cm})\end{array}$ & $\begin{array}{c}\text { Stem } \\
\text { diameter } \\
(\mathbf{m m})\end{array}$ & $\begin{array}{c}\text { Number } \\
\text { of } \\
\text { branches }\end{array}$ & $\begin{array}{c}\text { F.W* } \\
(\mathrm{g})\end{array}$ & $\begin{array}{l}\text { D.W*** } \\
\text { (g) }\end{array}$ & $\begin{array}{c}\text { Plant } \\
\text { height } \\
(\mathrm{cm})\end{array}$ & $\begin{array}{c}\text { Stem } \\
\text { diameter } \\
(\mathbf{m m})\end{array}$ & $\begin{array}{c}\text { Number of } \\
\text { branches }\end{array}$ & $\begin{array}{c}\text { F.W* } \\
(\mathrm{g})\end{array}$ & $\begin{array}{c}\text { D.W*** } \\
(\mathrm{g})\end{array}$ \\
\hline Control & 56.33 & 8.00 & 3.00 & 25.80 & 8.34 & 60.00 & 8.50 & 3.00 & 28.80 & 9.50 \\
\hline $\begin{array}{r}\text { Azospirillum } \\
\text { brasilense } \\
\text { M1 }\end{array}$ & 91.33 & 13.40 & 10.00 & 73.47 & 21.80 & 100.00 & 15.00 & 8.00 & 72.50 & 21.50 \\
\hline \begin{tabular}{|c|} 
Azotobacter \\
chroococcun \\
$\mathrm{M} 2$ \\
\end{tabular} & 68.67 & 9.70 & 4.00 & 32.60 & 10.11 & 72.33 & 11.00 & 4.00 & 35.80 & 12.00 \\
\hline \begin{tabular}{|c|} 
Bacillus \\
polymixa \\
M3 \\
\end{tabular} & 83.50 & 10.80 & 4.00 & 51.67 & 14.90 & 88.50 & 13.00 & 5.00 & 53.00 & 16.00 \\
\hline $\begin{aligned} \text { Serratia } & \text { sp. } \\
& \text { M4 }\end{aligned}$ & 84.00 & 9.60 & 7.00 & 54.67 & 14.93 & 88.50 & 13.00 & 5.00 & 54.67 & 16.00 \\
\hline L.S.D.at $5 \%$ & 7.50 & 1.40 & 3.46 & 11.60 & 3.13 & 6.67 & 1.10 & 2.46 & 9.60 & 2.95 \\
\hline
\end{tabular}

F.W* : fresh weight, D.W**: dry weight 
media increased by $66.6 \%, 67.5 \%, 166.7 \%, 151.7 \%$ and $126.3 \%$ for plant height, stem diameter, branches number, fresh and dry weights per transplant, when compared to the uninoculated media. These results indicate that the Rhizobacteria exhibited positive effects on the growth parameters of the inoculated host plants as previously reported by Zahir et al.(2004) and Mekhamar et al.(2007).

\subsubsection{Chemical analysis}

Data presented in Table (3) indicate that significant increases in $\mathrm{N}$ were observed in shoots and roots of the seedlings inoculated with Azospirillum which showed higher N content being 2.14 and $0.81 \%$, respectively than those recorded for transplants grown in other media. readily available for plant uptake, and this should be considered as a mechanism for enhanced plant growth ( Glick, 1995). Several reports suggested that PGPR can stimulate plant growth by increasing solubilization via releasing siderophores or organic acids and facilitate the uptake of mineral nutrients by the plant (Chabot et al ., 1996; Biswas et al ., $2000 \mathrm{a}$ and b ; Dazzo et al ., 2000).

These results are in agreement concerning such effects, It was similarly demonstrated by several authors Abo El-Soud et al. (2007), and Mekhamar et al.( 2007) who explained that improving effects arising from microbial inoculation are due to producing growth promoting substances such as auxins, gibbrillins and cytokinins.

Table (3): Nitrogen and Phosphorus contents (\%) Shoots and roots of Taxodium distichum transplants as influenced by PGPR inoculation in both seasons

\begin{tabular}{|l|l|l|l|l|l|l|l|l|}
\hline \multirow{2}{*}{ Characters } & \multicolumn{3}{|c|}{ The First season 2008/2009 } & \multicolumn{3}{c|}{ The Second season 2009/2010 } \\
\cline { 2 - 9 } & $\begin{array}{c}\text { Shoot } \\
\text { No }\end{array}$ & $\begin{array}{c}\text { Root } \\
\mathrm{N} \%\end{array}$ & $\begin{array}{c}\text { Shoot } \\
\mathrm{P} \%\end{array}$ & $\begin{array}{c}\text { Root } \\
\mathrm{P} \%\end{array}$ & $\begin{array}{c}\text { Shoot } \\
\text { N\% }\end{array}$ & $\begin{array}{c}\text { Root } \\
\text { N\% }\end{array}$ & $\begin{array}{c}\text { Shoot } \\
\text { P\% }\end{array}$ & $\begin{array}{c}\text { Root } \\
\text { P\% }\end{array}$ \\
\hline Control & 1.32 & 0.55 & 0.45 & 0.30 & 1.33 & 0.55 & 0.45 & 0.30 \\
\hline $\begin{array}{c}\text { Azospirillum } \\
\text { M1 }\end{array}$ & 2.14 & 0.80 & 0.55 & 0.53 & 2.11 & 0.81 & 0.54 & 0.50 \\
\hline $\begin{array}{c}\text { Azotobacter sp. } \\
\text { M2 }\end{array}$ & 1.48 & 0.52 & 0.47 & 0.32 & 1.45 & 0.50 & 0.45 & 0.33 \\
\hline $\begin{array}{c}\text { Bacillus } \text { sp. } \\
\text { M3 }\end{array}$ & 1.75 & 0.75 & 0.78 & 0.43 & 1.75 & 0.73 & 0.74 & 0.43 \\
\hline $\begin{array}{c}\text { Serratia sp. } \\
\text { M4 }\end{array}$ & 1.50 & 0.63 & 0.50 & 0.42 & 1.50 & 0.65 & 0.50 & 0.40 \\
\hline L.S.D. at 5\% & 0.24 & 0.18 & 0.15 & 0.10 & 0.23 & 0.18 & 0.15 & 0.10 \\
\hline
\end{tabular}

Additionally, it is well demonstrated that in both seasons chemical analysis of dried shoot and root of the seedlings which were grown in different inoculum strains in the growing media, reported in (Table 3) that the $\mathrm{P}$ content was considerably increased by addition of Bacillus polymixa to the bio composite media. The P content varied from $0.45 \%$ in the transplants grown in an uninoculated control media to $0.78 \%$ in transplants grown in media inoculated by Bacillus polymixa strain. This means that the addition of (PGPR) strains to the media increased $\mathrm{P}$ content in the transplants shoots and roots. Solubilization of mineral nutrients such as phosphorus and iron by PGPR made them more

\subsubsection{Anatomical study}

\subsubsection{The stem}

Data presented in Table (4) and Fig. (1) illustrate that stem diameter of Taxodium transplants in all treatments was thicker when compared to the control and reached their maximum thickness with treatment (M1), as it reached 18.5\% over the control. Predermal layer was thin in both (M1) and (M3), while in the other treatments, it was equal to the control. Cortex thickness decreased when applied all treatments and reached it's minimum decrease with treatments (M1) and (M3), where all treatments compensated the decrease in this trait by the highest increase in xylem thickness 

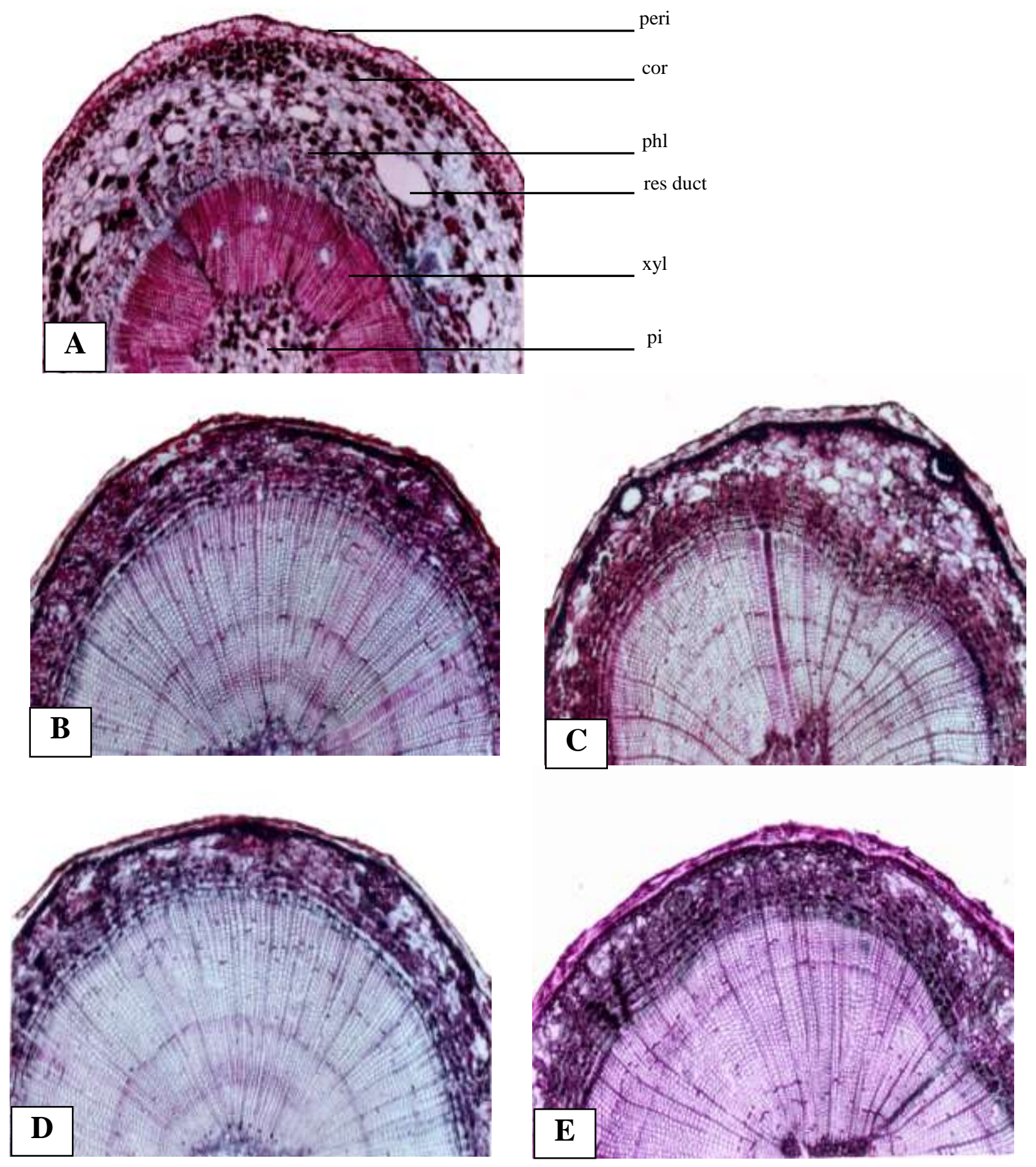

Fig. (1) : Transverse section through the middle part of the median internode of the main stem of Taxodium transplants A-Control, B- M1, C-M2, D-M3, E-M4

$(X=54)$ 
over the control. Fibrous thickness was more pronounced in the treatments (M1,M2 and M3). Thickness of phloem increased with treatments, (M1) and (M4) representing 33.3\% and 50\% increases over the control, respectively and that may play a role for increasing diameter and vigor. Thickness of xylem verified the importance for using treatments which exhibited the high increases than other traits in all treatments (M1, M2, M3 and the cortex it is proved that, in all applied treatments, the number of glands decrease than control also the disappear of these ducts in xylem in all treatments under studies. On the other hand, annual rings were fuzzy in the control where other treatments exhibited a clear rings which were 2- 3 rings in all treatments. These results of vigour growth attributed to the role of PGPR on seedlings growth, while the control treatment gave the lowest values which

Table( 4): Counts and measurements in (micron) of certain histological features in transverse sections through the middle part of the median internode of the main stem of bald cypress plants as affected by PGPR inoculation treatments (M1,M2,M3 and M4).

\begin{tabular}{|c|c|c|c|c|c|}
\hline Characteristics & Cont. & M1 & M2 & M3 & M4 \\
\hline Stem Thick & 3090.5 & 3662.5 & 3597 & 3487.5 & 3560 \\
\hline Priderm Thick & 150 & 112.5 & 150 & 112.5 & 150.00 \\
\hline Cortex Thick & 750.00 & 225 & 330 & 225 & 300.00 \\
\hline FiberousThick & - & 150 & 150.00 & 150.00 & - \\
\hline Phloem Thick & 300.00 & 400 & 300.00 & 300.00 & 450.00 \\
\hline $\begin{array}{c}\text { Xylem Thick } \\
\text { Pith Thick }\end{array}$ & 825 & 2025 & 1907 & 1950 & 1970.00 \\
\hline $\begin{array}{c}\text { No.of rating gland } \\
\text { in cortex }\end{array}$ & 11.00 & 720 & 750.00 & 750 & 712.50 \\
\hline $\begin{array}{c}\text { No.of rating gland } \\
\text { in xylem }\end{array}$ & 8.00 & - & 7.00 & 6.00 & 8.00 \\
\hline Annual ring & Not clear & 3 rings & 3 rings & 3 rings & 2 rings \\
\hline
\end{tabular}

M1: Azospirillum brasilense

M3: Bicillus polymixa

M2: Azotobacter chroococcum

M4: Serattia sp.

M4) which recorded increases Nitrogen and Phosphorus contents (\%)in shoots and roots of Taxodium distichum as influenced by PGPR inoculation in both seasons up to 145.5, 131.2,136.4 and $138.8 \%$ over the control, respectively. So this increase in main value of this traits affected pith area which showed low values in all treatments than the control. According to the number of glands in exhibited the importance of using PGPR to improve the growth of Taxodium transplants.

\subsubsection{The root}

Data presented in Table (5) and Fig. (2) indicate that anatomical features of the root did not show a considerable differences between the control and other treatments except the treatment (M1) which showed an increase in root diameter by $2.7 \%$ over

Table( 5) : Counts and measurements in micron of certain histological features in transverse sections through the middle part of the lateral root of bald cypress plants as affected by 4 treatments (M1-M2-M3 and M4).

\begin{tabular}{|l|c|c|c|c|c|}
\hline Characteristics & Cont. & M1 & M2 & M3 & M4 \\
\hline Root Thick & 1840.00 & 1890.20 & 1557.00 & 1585.00 & 1835.00 \\
\hline Epi.Thick & 18.75 & 18.75 & 18.75 & 18.75 & 18.75 \\
\hline Cortex Thick & 963.00 & 1229.00 & 950.00 & 962.50 & 1195.00 \\
\hline Vs.Cylender Thick & 675.00 & 412.50 & 420.00 & 412.50 & 450.00 \\
\hline Pith Thick & 168.75 & 168.75 & 131.25 & 131.25 & 150.00 \\
\hline
\end{tabular}

M1: Azospirillum brasilense M2: Azotobacter chroococcum

M3: Bacillus polymixa M4: Serattia sp. 

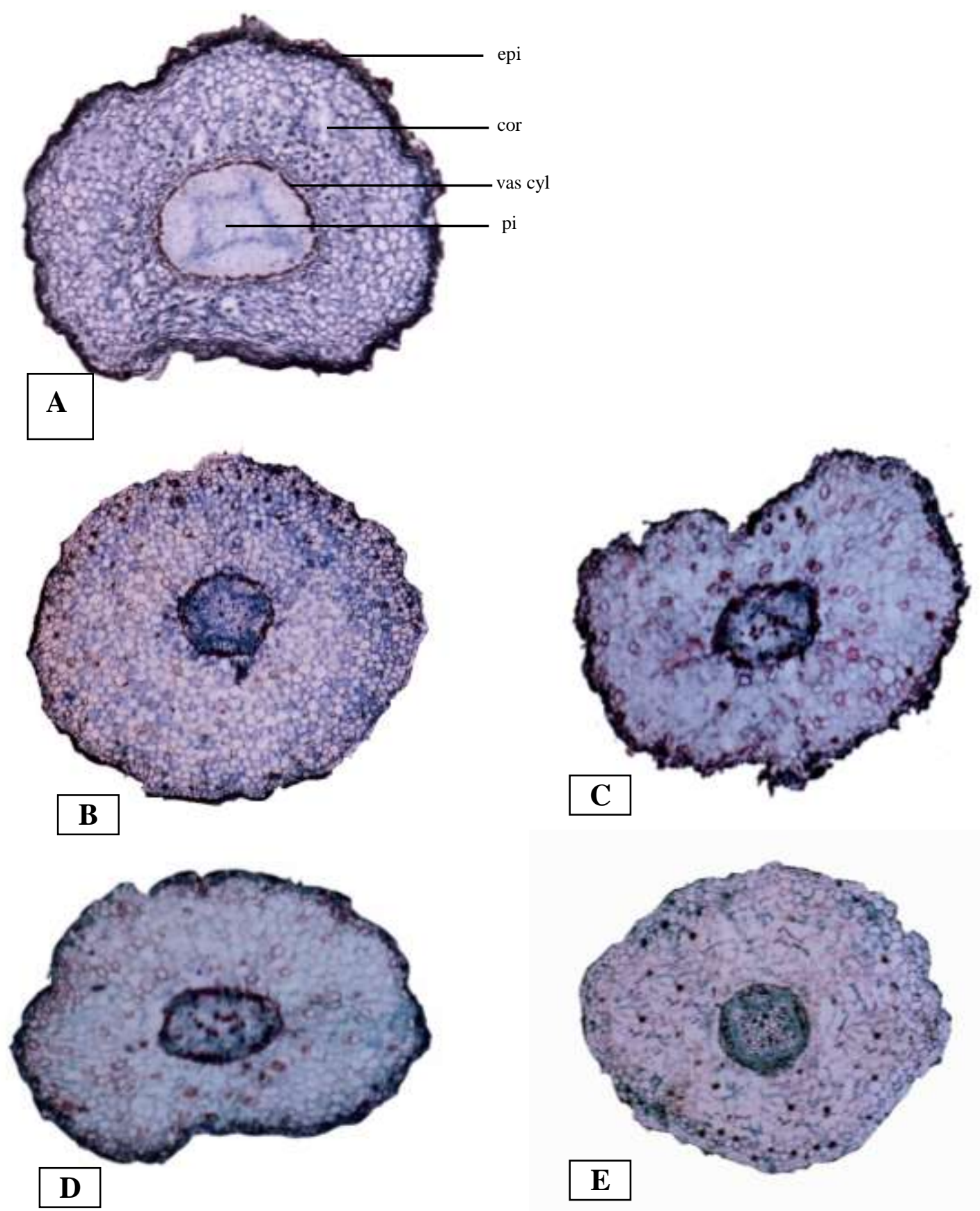

Fig. ( 2 ): Transverse section through the middle part of the lateral root of Taxodium transplants A-Control , B-M1. C-M2, D-M3, E-M4 $(X=50)$ 
showed an increase in root diameter by $2.7 \%$ over the control. Thickness of cortex recorded high value for both treatments (M1) and (M4) which recorded $27.6 \%$ and $24.09 \%$ increases respectively, over the control. While, other treatments caused a decrease below the control. Other traits were either equal or decreased than uninoculated one.

\section{DISCUSSION}

Many results are inconclusive, but encouraging enough to improve selection procedures and the production of quality inocula for practical application. As PGPR-mediated processes involved in nutrient cycling include those related to nonsymbiotic nitrogen-fixation, and those responsible for increasing the availability of phosphate and other nutrients in the soil. Many asymbiotic diazotrophic bacteria have been described and tested as biofertilizers Kennedy et al., (2004). The selection of effective PGPR diazotrophs is critical for further development of this technology. Azospirillum species are also considered to be PGPR Lucy et al. (2004) and Zahir et al. (2004). A significant activity of these bacteria is the production of auxin-type phytohormones that affect root morphology and, thereby, improve nutrient uptake from the soil. This may be more important than their $\mathrm{N}_{2}$-fixing activity. Azospirillum species are being used as seed inoculants under field conditions Dobbelaere et al., (2001); Lucy et al., (2004); Zahir et al., (2004).Despite many studies reporting the benefits of Azospirillum inoculation, some studies present inconsistent results. However, it can be assumed that, upon establishing appropriate management practices, the use of these inoculants will have a beneficial effect on plant nutrition. It has recently been postulated that an additional mechanism for plant growth promotion by PGPR could be their altering of microbial rhizosphere communities Ramos et al.(2003). Agreeing with such an indirect mechanism, it would be interesting to evaluate the actual impact of this activity in rhizosphere biology. Rhizobacteria that exert beneficial effects on plant growth and development are referred to as plant growth promoting rhizobacteria PGPR. In recent years, the use of PGPR to promote plant growth has increased in various parts of the world. PGPR can affect plant growth by the production and release of secondary metabolites (plant growth regulators/ phytohormones / biologically active substances), preventing deleterious effects of phytopathogenic organisms in the rhizosphere and / or facilitating the availability and uptake of certain nutrients from the root environment . Selection of effective PGPR is the most critical aspect to have maximum benefits from this technology. (Glick 1995; Nguyen et al. 2002; Zahir et al ., 2004; Abo EL-Soud, et al.,2007 and Mekhamar et al., 2007).

\section{Conclusion}

Inoculation with Plant Growth Promoting Rhizobacteria(PGPR) comparatively enhance the growth of Taxodium distichum transplants and shortening the time of seedling growth.

\section{REFERENCES}

Abdel Wahab A.F. and Ahmed A.S. (2003). Preparation of bio-organic materials for their utilization as soil amendment and growth media .Annals Agric.Sci., Ain Shams Univ., Cairo, 48(2):561-572.

Abo El-Soud A.A., Kandil B.A.A. and Hasouna B.A. (2007) . Response of wheat growth and yield to N2-fixer bacteria combined with plant growth promoting rhizobacteria. Egypt. J. of Appl . Sci ., 22: 670-681.

Al-Kahal A.A., Ragab A. A., Saida S. A. and Omar S. A. (2003). Use of plant growth promoting rhizobacteria for controlling faba bean roots disease caused by Fusarium oxysporum. Eleventh conference of Microbiology; Cairo; Egypt; Oct.12-14; p.63-70.

Bashan Y.(1999) .Interactions of Azospirillum spp. In soils: a review. Biol. Fertil. Soils.29:246256.

Bashan Y. and de Bashan L.E. (2002). Protection of tomato seedlings against infection by Pseudomonas syringae pv.tomato by using the plant growth promoting: bacterium Azospirillum brasilense.App. Enivron. Microbiol. 68:2637-2643.

Belimov A.A., Safronova V.I., Sergeyeva T.A., Egorova T.N., Matveyeva V. A., Tsyganov V. E., Borisovp A.Y., Tikhonovich I.A., Kluge C., Preisfeld A., Dietz K.J. and Stepanok V.V.(2001). Characterization of plant growth promoting rhizobacteria isolated from polluted soils and containing 1aminocyclopropane-1-carboxylate deaminase. Can . J. Microbial. 47:642-652.

Biswas J.C., Ladha J.K. and Dazzo F.B. (2000a). Rhizobia inoculation improves nutrient 
uptake and growth of lowland rice. Soil Sci . Am . J. 64: 1644-1650.

Biswas J.C., Ladha J.K., Dazzo F.B., Yanni Y.G. and Rolfe B.G. (2000b).Rhizobial inoculation influences seedling vigor and yield of rice . Agron. J., 92: 880-886.

Bowers L. J. and Melhuish J. H. (1988).Silcon content in wood and bark of baldcypress compared to loblolly pine and southern red oak densities by membrane filter technique . J. Appl . Bacteriol. , 41:311-313.

Chabot R., Antoun H. and Cescas, M. P. (1996). Growth promoting of maize and lettuce by phosphate-solubilizing Rhizobium leguminosarum biovar phaseoli. Plant Soil, 184: 311-321.

Dazzo F. B., Yanni Y. G., Rizk R., deBruijn F. J., Rademaker J., Squartini A., CorichV., Mateos P. and Martinez-Molina E. (2000). Progress in multinational collaborative studies on the beneficial association between Rhizobium leguminosarum bv. Trifolii and rice. In " The Quest for Nitrogen Fixation in Rice"( J. K . Ladha and Reddy P. M. et al., Eds.), p. 167189. IRRI, Los Banos, Philippines.

Dobbelaere S., Croonenborgh A., and Thys A. (2001). Response of agronomically important crops to inoculation with Azospirillum. Australian Journal of Plant Physiology28,1-9.

Glick R. B. (1995). The enhancement of plant growth promotion by free living bacterial . Can. J. Microbiol.41: 109-117.

Gutierrez Manero F.J., Acero N., Lucas J.A. and Probanza A. (1996). The influence of native rhizobacteria on European alder (Alnus glutinosa (L.) Gaertn.) growth . Plant and Soil 182:67-74.

Hegazi N.A. and Neimela S. (1976) . A note on the estimation of Azotobacter densities by membrance filter technique .J.Appl.Bacteriol.,41:311-313.

Hubble D. H., Tein T. M. , Gaskins M. H. and Lee J. (1979). Physiological interactions in Azospirillum-grass root association . In Associati- ve N2 - Fixtion. Eds . P. B Vose and A P Ruschel. CRC Press, Lnc., Boca Raton, FL, USA .

Kennedy I.R., Choudhury A.T.M.A. and Kecskes M.L. (2004). Non-symbiotic bacterial diazotrophs in crop-farming systems: can their potential for plant growth promotion be better exploited? Soil Biology and Biochemistry36,1229-1244

King E. J. (1951) . Micro-Analysis in Medical Biochemistry.2th ED., Curchill Publishing Co., London.

Lucy M., Reed E., and Glick B.R. (2004). Application of free living plant growth promoting rhizobacteria. Antonie van Leeuwenhoek Internationa Journal of General and Molecular Microbiology86,1-25.

Mei R.L., Chem B .Lu.S. and Chen Y-x . (1984). Field application of yield increasing bacteria (Y\B). Report of Department of Plant Protection . Beijing Agricultural University Beijing . China .

Mekhamar G.A.A.(2001) .Response of faba bean plants to co-inoculation with Rhizobium leguminosarum and Bacillus megatherium under different level of phosphate fertilization in newly reclaimed lands. J. Agric . Sci., Mansoura Univ., 26:8129-8140.

Mekhamar G.A.A., Badawi F.Sh.F., Radwan T.E.E. and Hasouna B.A. (2007). Assessment of multi-strain PGPRs biofertilization as compared to sole-strain or mineral $\mathrm{N}$ fertilization on wheat plants grown in clay soil in Egypt . Egypt .J. Biotechnol ., 25:2744.

Muller M., Deigele C. and Ziegler H. (1989). Hormonal interactions in the rhizosphere of maize (Zea mays L.) and their effect on plant development . Z. Pflanzen . Bodenk ., 152:242- 254.

Nguyen T.H., Kennedy I.R. and Royghley R.J. (2002). The response of field- grown rice to inoculation wth multi-strain biofertilizer in Hanoi district, Vietnam . In: Kennedy , I.R., Choudhury, A.T.M.A.(Eds), Biofertilizars in Action. Rural . Industries Research and Development Corporation, Canberra, Australia.

Oberhansli T., Defago G. and Haas D. (1990) . Influence of tryptophan side chain oxidase (TSO) of a Pseudomonas fluorescens strain on the indole- 3 acetic acid (IAA) production and on the suppression of take all of wheat and black root of tobacco under gnotobiotic conditions. In Abstracts Second International Workshop on Plant Growth-Promoting Rhizobacteria. Interlaken, Switzerland Oct. 14-19, 1 . 
Piper C.S.(1950). Soil and Plant Analysis $1^{\text {st }}$ Ed. Interescience Publisher, N.Y.

Pregl P. (1945). Quantitative Organic Microanalysis. $4^{\text {th }}$ Ed., Churchill Publishing Co., London. Press, Boca Raton, FL.

Ramos B., García J.A.L., Probanza A., Barrientos M.L. and Gutiérrez Mañero F.J.(2003). Alterations in the rhizobacterial community associated with European alder growth when inoculated with PGPR strain Bacillus licheniformis. Environmental and Experimental Botany49,61-68. on wheat. Plant and Soil 212, 155-

Reddy M. S. and Rahe J. E.(1989). Growth effect associated with seed bacterization non correlated with populations of Bacillus subtilis inoculated in onion seedling rhizospheres. Soil Biol . Biochem . 21, 373378.

Schippers B. A., Bakker W., Bakker P. and Van Peer R. (1991). Beneficial and deleterious effect of $\mathrm{HCN}$-producing Pseudomonas on rhizosphere in teractions. Plant and Soil 129, 97-104.

Selvadurai E.L., Brown A. E. and Hamilton J. T. G. (1991). Production of indole -3- acitic acid analogues by strains of Bacillus cereus in relation to their influence on seedling development . soil . Biol Biochem . 23, 401403.
Steel R. G. and Torrie S. H. (1980). Principles and procedures Statistics $2^{\text {nd }}$ Ed. McGraw-Hill Inc. Transactions of Kentucky Academy of Science . 49 (1-2):1-7.

Vanstocken M., Michiels K., Vanderleydem J. and Van Gool A. (1987) . Transposon mutagenesis of Azospirilum brasilense and Azospirillum lipofermm, Physical and lysis of Tn5 and mobinsertion mutants. Appl. Environ. Microblol., 53:410-415.

Walker L. C. (1990). Forests: A Naturalist's Guide to Trees and Forests Ecology. Wiley Nature Editions. NewYork: John Wiley \& Sons Inc. 288pp.

Wilhite L.P. and Toliver J.R.(1990).Taxodium distichum (L.) Rich. baldcypress. In: Burns, Russell M., Honkala, Barbara H., technical coordinators . Silvics of North America.Volume 1. Conifers. Agric. Handb . 654. Washington, DC : U.S. Department of Agriculture , Forest Service : 563572.[13416].

Willey R. L. (1971) . Microtechniques , A Laboratory Guide . Mamillan Publishing Co. , Inc . New york pp99.

Zahir Z., Arshad A.M. and Frankenberger W. T. (2004). Plant Growth Promoting Rhizobacteria: Applications and Perspectives In Agriculture.Advances in Agronomy, Volume 81 By Academic Press.

\footnotetext{
تاثير بعض البكتيريا المشجعة للنمو على النمو الخضري ومحتوي النيتروجين والفوسفور

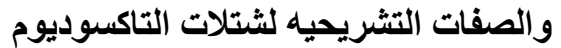


2.

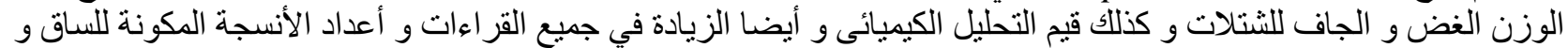
الجذر.

3. أدي استخدام لقاح Azospirillum brasilense إلي حدوث زيادة معنوية في نسبة المحتوي النبتروجيني في المجموع الخضري

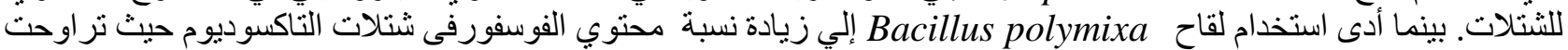

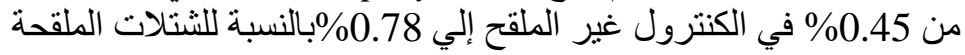

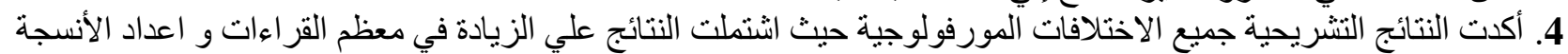
المكونة للساق بالإضافة إلي ظهور الاختلافات في التركيب التشريحي للجذر ايضا.

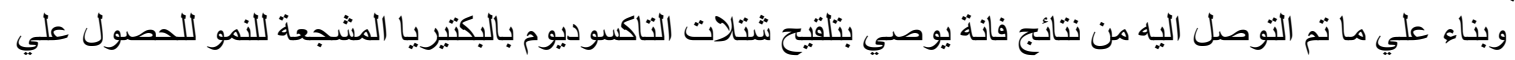

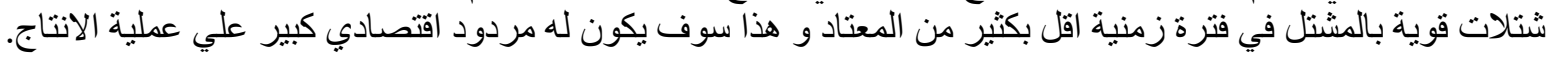

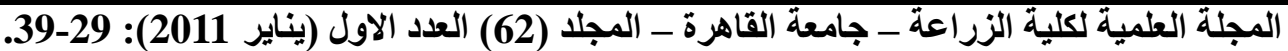

